\title{
Erratum to: Bearing fruit: flower removal reveals the trade-offs associated with high reproductive effort for lowbush blueberry
}

\author{
Alex W. Bajcz ${ }^{1}$ • Francis A. Drummond $^{1}$
}

Published online: 20 August 2017

(C) Springer-Verlag GmbH Germany 2017

\section{Erratum to: Oecologia}

DOI 10.1007/s00442-017-3908-2

Unfortunately, the equation number was incorrectly published in the original article and the same is corrected here in this erratum. The original article was corrected.

The correct equation should be:

TA

$$
=\frac{(0.005 \mathrm{~N} \mathrm{NaOH} \times \mathrm{mL} \text { titrant } \times 64 \text { milliequivalencies of } \mathrm{NaOH})}{10} .
$$

The online version of the original article can be found under doi:10.1007/s00442-017-3908-2.

$\triangle$ Alex W. Bajcz

alex.bajcz@maine.edu

1 School of Biology and Ecology, University of Maine at Orono, 5722 Deering Hall, Orono, ME 04469, USA 